DOI: $10.19195 / 0137-1134.117 .8$

\author{
ARIEL PRZYBYŁOWICZ \\ ORCID: 0000-0003-4219-0984 \\ Uniwersytet Wrocławski
}

\title{
W SPRAWIE PODLEGANIA NIEFORMALNYCH OPIEKUNÓW OSÓB NIESAMODZIELNYCH UBEZPIECZENIU WYPADKOWEMU
}

\begin{abstract}
Abstrakt: Autor rozważa kwestię podlegania ubezpieczeniu wypadkowemu opiekunów osób niesamodzielnych. W pierwszej kolejności definiuje pojęcia opiekuna oraz osoby niesamodzielnej. W dalszej części rozważa konstrukcję prawną opłacania składki na ubezpieczenia emerytalne i rentowe za opiekunów osób niesamodzielnych. Stosując wykładnię językową i systemową, dochodzi do wniosku, że jest to konstrukcja prawna inna niż klasyczny tytuł ubezpieczenia. W kontekście opiekunów ma to doniosłe skutki prawne, gdyż pozbawia ich ochrony ubezpieczenia wypadkowego. Zastosowana przez ustawodawcę konstrukcja prawa powoduje, że nie podlegają oni temu ubezpieczeniu, choć sprawowanie opieki jest okolicznością o zwiększonym ryzyku wystąpienia wypadku. Na zakończenie autor postuluje, aby uszczerbki na zdrowiu opiekunów spowodowane wypadkami przy opiece objąć ochroną w ramach systemu świadczeń odszkodowania socjalnego.
\end{abstract}

Słowa kluczowe: ubezpieczenia społeczne, ubezpieczenia wypadkowe, tytuł ubezpieczenia, opiekunowie

\section{WPROWADZENIE}

Przedmiotem niniejszego opracowania jest przedstawienie zasad podlegania ubezpieczeniu wypadkowemu opiekunów osób niesamodzielnych. Polski ustawodawca nie posługuje się wprawdzie pojęciem „osoba niesamodzielna” czy „niesamodzielność”, jednakże są to terminy powszechnie używane w języku prawniczym ${ }^{1}$. Omawiane zagadnienie ma istotne znaczenie praktyczne, gdyż

1 Przykładowo A. Przybyłowicz, O pojęciu niesamodzielności w księdze XI niemieckiego kodeksu socjalnego - Ubezpieczenie pielęgnacyjne, PiZS 2013, nr 10 s. 10-17; R. Bakalarczyk, Polityka wsparcia nieformalnych opiekunów niesamodzielnych osób starszych. Na podstawie zmian prawnych w latach 2003-2015, Warszawa 2018; D.E. Lach, Niesamodzielność jako ryzyko socjalne, Poznań 2018. 
niesamodzielność jest traktowana jako nowe ryzyko socjalne ${ }^{2}$, którego skutki dotykają nie tylko osobę niesamodzielną bezpośrednio, lecz także osoby jej najbliższe, które sprawują nad nią opiekę i ją pielęgnują ${ }^{3}$, co często ma negatywne konsekwencje $\mathrm{w}$ odniesieniu do nabywania uprawnień do świadczeń z ubezpieczenia społecznego jako podstawowej części systemu zabezpieczenia społecznego w Polsce czy szerzej - do zabezpieczenia społecznego tychże osób ${ }^{4}$. Mając na uwadze skalę zjawiska, która wciąż rośnie, polski ustawodawca przewidział określone rozwiązania, które przynajmniej w zakresie nabywania ekspektatyw emerytalnych mają łagodzić w określonym stopniu skutki sprawowania opieki przez nieformalnego opiekuna. Analiza przyjętych rozwiązań prowadzi jednak do wniosku, że ustawodawca w żaden sposób nie zapewnia ochrony prawnej opiekunom w odniesieniu do ryzyka wypadku w zakresie sprawowania opieki i pielęgnacji (określanym dalej jako wypadek przy opiece), choć niewątpliwie są to czynności, które można określić jako wręcz wielce wypadkogenne.

W niniejszym opracowaniu, posługując się metodą dogmatycznoprawną, przeanalizuję rozwiązania prawne obowiązujące we wskazanym zakresie.

\section{KWESTIE TERMINOLOGICZNE}

Jak wskazałem, niesamodzielność jest obecnie uznawana za nowe ryzyko socjalne. Mimo konkretnych propozycji ustawodawczych ${ }^{5}$ czy doktrynalnych ${ }^{6}$ terminy „niesamodzielność” czy „osoba niesamodzielna” nie mają ustawowej definicji. Pojęcia osoby niesamodzielnej i nieformalnego opiekuna osoby niesamodzielnej nie są zatem pojęciami języka prawnego, jednak powszechnie używane są w literaturze prawniczej. Omawianie tych pojęć i propozycji nie jest przedmiotem niniejszego opracowania. Na jego cele należy jednak te pojęcia zdefiniować,

2 Np. G. Uścińska, Ryzyko jako przesłanka ochrony w systemie zabezpieczenia społecznego, „Polityka Społeczna” 40, 2013, nr 11-12, s. 6; Z. Czepulis-Rutkowska, Nowe ryzyka socjalne, „Polityka Społeczna” 40, 2013, nr 11-12, s. 13; A. Przybyłowicz, Ubezpieczenie pielęgnacyjne w Republice Federalnej Niemiec, Warszawa 2017, s. 217-228; szeroko na ten temat również D.E. Lach, op. cit., s. 56-113.

3 A. Przybyłowicz, Społeczne ubezpieczenie pielegnacyjne a rola opieki krewniaczej $w$ Niemczech, „Ubezpieczenia Społeczne. Teoria i Praktyka” 2016, nr 4, s. 68, 71-72. Choć uwagi dotyczą sytuacji w Niemczech przed rokiem 1995, są one w pełni aktualne w odniesieniu do obecnej sytuacji w Polsce; zob. też R. Bakalarczyk, który wprost wskazuje na ryzyka socjalne opiekuna osoby starszej - idem, op. cit., s. 37-42.

${ }^{4}$ R. Bakalarczyk, Deficyt bezpieczeństwa emerytalnego opiekunów osób niesamodzielnych jako skutek dezaktywizujacego zawodowo systemu opieki w Polsce, „Ubezpieczenia Społeczne. Teoria i Praktyka" 2017, nr 4, s. 96-98.

5 Projekt ustawy o pomocy osobom niesamodzielnym opracowany przez Grupę Roboczą ds. przygotowania projektu ustawy o pomocy osobom niesamodzielnym, http://mieczyslawaugustyn.pl/ wp-content/uploads/2018/06/1181-z-dnia-4-maja-2018-r.1.pdf (dostęp: 29.03.2019).

${ }^{6}$ Np. D.E. Lach, op. cit., s. 107-113. 
z uwzględnieniem przepisów prawa ubezpieczenia społecznego. Do wskazanych celów wystarczające zdaje się de lege lata powiązanie pojęcia niesamodzielności z pojęciem niepełnosprawności lub niezdolności do niesamodzielnej egzystencji, co w kontekście tematyki niniejszego opracowania należy interpretować z przepisów art. 6 ust. 2 i 6 ust. 2 a ustawy o systemie ubezpieczeń społecznych ${ }^{7}$, w związku z przepisami art. 42 ustawy o pomocy społecznej ${ }^{8} \mathrm{i}$ art. $16 \mathrm{a}$ ust. $1 \mathrm{i} 17$ ust. 1 w związku z art. 3 pkt 20-21 ustawy o świadczeniach rodzinnych ${ }^{9}$. W tym kontekście należy wyinterpretować, komu i w jakich sytuacjach ustawodawca przyznaje określone uprawnienia.

Zgodnie z art. 6 ust. 2 u.s.u.s. zasady podlegania ubezpieczeniom emerytalnemu i rentowym osób rezygnujących $\mathrm{z}$ zatrudnienia $\mathrm{w}$ związku $\mathrm{z}$ koniecznością sprawowania bezpośredniej, osobistej opieki nad długotrwale lub ciężko chorym członkiem rodziny oraz wspólnie niezamieszkującymi matką, ojcem lub rodzeństwem, za które ośrodek pomocy społecznej opłaca składkę, regulują przepisy o pomocy społecznej. Tym samym ustawodawca odsyła do art. 42 ust. 1 u.p.s., zgodnie z którym za osobę, która zrezygnuje z zatrudnienia w związku z koniecznością sprawowania bezpośredniej, osobistej opieki nad długotrwale lub ciężko chorym członkiem rodziny ${ }^{10}$ oraz wspólnie niezamieszkującymi matką, ojcem lub rodzeństwem, ośrodek pomocy społecznej opłaca składkę na ubezpieczenia emerytalne i rentowe od kwoty kryterium dochodowego na osobę w rodzinie, jeżeli dochód na osobę w rodzinie osoby opiekującej się nie przekracza $150 \%$ kwoty kryterium dochodowego na osobę w rodzinie i osoba opiekująca się nie podlega obowiązkowo ubezpieczeniom emerytalnemu i rentowym z innych tytułów lub nie otrzymuje emerytury albo renty (oraz spełnia dodatkowe warunki określone w u.p.s., których nie trzeba w tym miejscu przybliżać).

Zgodnie natomiast z art. 6 ust 2a u.s.u.s. za osobę pobierającą świadczenie pielęgnacyjne, specjalny zasiłek opiekuńczy albo zasiłek dla opiekuna wójt, burmistrz lub prezydent miasta opłaca składkę na ubezpieczenia emerytalne i rentowe od podstawy odpowiadającej wysokości danego świadczenia. Wypłatę wymienionych świadczeń opiekuńczych regulują przepisy u.ś.r. (art. 16a i art. 17) oraz ustawa z dnia 4 kwietnia 2014 roku o ustaleniu i wypłacie zasiłków dla opiekunów ${ }^{11}$. Na gruncie wskazanych przepisów za osobę niesamodzielną należy uznać osobę

7 Ustawa z dnia 13 października 1998 roku o systemie ubezpieczeń społecznych, tekst jedn. Dz.U. z 2019 r. poz. 300 ze zm. (dalej: u.s.u.s.).

${ }^{8}$ Ustawa z dnia 12 marca 2004 roku o pomocy społecznej, tekst jedn. Dz.U. z 2018 r. poz. 1908 ze zm. (dalej: u.p.s.).

9 Ustawa z dnia 28 listopada 2003 roku o świadczeniach rodzinnych, tekst jedn. Dz.U. z 2018 r. poz. 2220 ze zm. (dalej: u.ś.r.).

10 Co do rozumienia pojęcia długotrwałej i ciężkiej choroby zob. W. Maciejko, Instytucje pomocy spotecznej, Warszawa 2009, s. 136-143.

11 Tekst jedn. Dz. U. z 2017 r. poz. 2092; szerzej na temat zasiłku dla opiekuna zob. A. Przybyłowicz, Zasitek dla opiekuna, [w:] Wielka Encyklopedia Prawa, t. 12. Prawo socjalne, red. H. Szurgacz, Warszawa 2017, s. 391-392. 
legitymującą się orzeczeniem o znacznym stopniu niepełnosprawności albo orzeczeniem o niepełnosprawności łącznie ze wskazaniami: konieczności stałej lub długotrwałej opieki lub pomocy innej osoby w związku ze znacznie ograniczoną możliwością samodzielnej egzystencji oraz konieczności stałego współudziału na co dzień opiekuna dziecka w procesie jego leczenia, rehabilitacji i edukacji. Zgodnie z definicją ustawową zawartą w art. 2 pkt 10 ustawy z dnia 27 sierpnia 1997 roku o rehabilitacji zawodowej i społecznej oraz zatrudnianiu osób niepełnosprawnych ${ }^{12}$ niepełnosprawność oznacza trwałą lub okresową niezdolność do wypełniania ról społecznych z powodu stałego lub długotrwałego naruszenia sprawności organizmu, w szczególności powodującą niezdolność do pracy, do znacznego zaś stopnia niepełnosprawności zalicza się osobę z naruszoną sprawnością organizmu, niezdolną do pracy albo zdolną do pracy jedynie w warunkach pracy chronionej i wymagającą, w celu pełnienia ról społecznych, stałej lub długotrwałej opieki i pomocy innych osób w związku z niezdolnością do samodzielnej egzystencji (art. 4 ust. 1 u.r.z.i.s.). Natomiast niezdolność do samodzielnej egzystencji oznacza naruszenie sprawności organizmu w stopniu uniemożliwiającym zaspokajanie bez pomocy innych osób podstawowych potrzeb życiowych, za które uważa się przede wszystkim samoobsługę, poruszanie się i komunikację (art. 4 ust. 4 u.r.z.i.s.). Dla jasności należy wskazać, że o stopniu niepełnosprawności orzeka się wobec osób powyżej 16 roku życia; do ukończenia tego wieku orzeka się jedynie o niepełnosprawności, jeżeli mają naruszoną sprawność fizyczną lub psychiczną o przewidywanym okresie trwania powyżej 12 miesięcy, z powodu wady wrodzonej, długotrwałej choroby lub uszkodzenia organizmu, powodującą konieczność zapewnienia im całkowitej opieki lub pomocy w zaspokajaniu podstawowych potrzeb życiowych w sposób przewyższający wsparcie potrzebne osobie w danym wieku (art. 4 a ust. 1 u.r.z.i.s.).

Nie wnikając w tym miejscu w teoretyczne i praktyczne problemy przytoczonych definicji, należy skonstatować, że dla celów niniejszego opracowania na gruncie przepisów prawa ubezpieczeń społecznych za nieformalnego opiekuna należy uznać osobę fizyczną, o której mowa w art. 6 ust. 2 i 6 ust. 2a ustawy systemowej, to znaczy osobę rezygnującą z zatrudnienia (u.p.s.) lub rezygnującą z zatrudnienia albo niepodejmującą zatrudnienia (u.ś.r.) w celu sprawowania bezpośredniej, stałej opieki nad osobą wymagającą takiej opieki z uwagi na stan zdrowia, spełniające dodatkowe przesłanki określone odpowiednio w art. 42 u.p.s. lub art. 16a albo 17 u.ś.r. Osoby te mogą zostać określone mianem nieformalnych opiekunów, gdyż czynności z zakresu opieki i pielęgnacji wykonują nie jako swą działalność zarobkową (w ramach stosunku pracy czy zlecenia, co stanowiłoby dla nich „klasyczny” tytuł ubezpieczenia społecznego). Przywołana kategoria nie wyczerpuje jednak w całości zakresu znaczeniowego tego pojęcia. Należy do niej zaliczyć również osoby, które faktycznie sprawują opiekę nad osobami

12 Tekst jedn. Dz.U. z 2018 r. poz. 511 ze zm. (dalej: u.r.z.i.s.). 
niesamodzielnymi w wyżej przyjętym rozumieniu, nie rezygnując jednak ze swej działalności zarobkowej (a zatem nie rezygnują z zatrudnienia lub jego podjęcia), zatem okoliczność sprawowania opieki nie stanowi dla nich tytułu ubezpieczeń emerytalnego i rentowych, gdyż podlegają tym ubezpieczeniom z tytułu wykonywanej działalności zarobkowej, na ogólnych zasadach wynikających z art. 6 ust. 1 u.s.u.s. (ewentualnie w związku z art. 9 tej ustawy).

Nadmienię ponadto, że mimo pewnych wątpliwości terminologicznych co do określenia wskazanych opiekunów mianem nieformalnych, wydaje się ono językowo lepsze niż „nieprofesjonalny” opiekun w odróżnieniu od opiekunów profesjonalnych, dla których sprawowanie opieki jest rodzajem wykonywanej pracy zarobkowej — w tym zaś kontekście następuje rozróżnienie. Pojęcie „nieprofesjonalny opiekun" ma bowiem pewne negatywne zabarwienie konotacyjne. Ponadto pojęcie „nieformalny opiekun” jest już stosowane w literaturze naukowej ${ }^{13}$.

\section{PODLEGANIE NIEFORMALNYCH OPIEKUNÓW UBEZPIECZENIOM EMERYTALNEMU I RENTOWYM}

Podleganie ubezpieczeniu wypadkowemu jest ściśle związane z podleganiem ubezpieczeniom emerytalnemu i rentowym, to znaczy podlegają mu obowiązkowo wszystkie osoby podlegające ubezpieczeniom emerytalnemu i rentowym (art. 12 ust. 1 u.s.u.s.), z wyłączeniem osób wyraźnie wskazanych w art. 12 ust. 2 u.s.u.s. ${ }^{14}$ Dlatego też, aby ustalić, czy nieformalni opiekunowie podlegają ubezpieczeniu wypadkowemu, należy przeanalizować, czy podlegają oni ubezpieczeniom emerytalnemu i rentowym. Nie ulega wątpliwości, że sprawowanie opieki nie będzie tytułem ubezpieczenia dla drugiej wyróżnionej kategorii opiekunów nieformalnych, czyli tych, którzy opiekę sprawują bez rezygnacji z pracy zarobkowej lub z podjęcia pracy zarobkowej. Dla tych osób to wykonywana praca zarobkowa będzie tytułem ubezpieczenia emerytalnego i rentowych, a w konsekwencji również ubezpieczenia wypadkowego. Fakt wykonywania pracy zarobkowej przez opiekuna automatycznie wyłącza możliwość uiszczania składek na ubezpieczenia emerytalne i rentowe w przepisach zarówno u.ś.r., jak i u.p.s.

Bardziej skomplikowana okazuje się kwestia podlegania tym ubezpieczeniom pierwszej wyróżnionej kategorii opiekunów, czyli rezygnujących z zatrudnienia lub z jego podjęcia. Jak wskazano, zgodnie $\mathrm{z}$ art. 6 ust. 2 u.s.u.s. zasady podlegania ubezpieczeniom emerytalnemu i rentowym osób rezygnujących z zatrudnienia w związku z koniecznością sprawowania bezpośredniej, osobistej opieki nad dłu-

13 Np. cytowany już R. Bakalarczyk, Polityka wsparcia nieformalnych...

14 I. Jędrasik-Jankowska, Ubezpieczenie społeczne, t. 1. Część ogólna, Warszawa 2003, s. 84; A. Radzisław, [w:] Ustawa o systemie ubezpieczeń społecznych. Komentarz, red. J. Wantoch-Rekowski, Warszawa 2015, s. 134-135. 
gotrwale lub ciężko chorym członkiem rodziny oraz wspólnie niezamieszkującymi matką, ojcem lub rodzeństwem, za które ośrodek pomocy społecznej opłaca składkę, regulują przepisy o pomocy społecznej, czyli art. 42 u.p.s., który wymaga spełnienia wielu dodatkowych przesłanek, $\mathrm{w}$ tym przewiduje określone kryterium dochodowe. Niespełnianie tego kryterium skutkuje tym, że za opiekunów nie będą odprowadzane składki na ubezpieczenia emerytalne i rentowe.

Analiza językowa przepisu art. 6 ust. 2 u.s.u.s. prowadzi prima facie do wniosku, że sprawowanie opieki w warunkach określonych w art. 42 u.p.s. ustawodawca traktuje jako tytuł ubezpieczenia emerytalnego i rentowych, określając jednocześnie płatnika składek, którym zgodnie z brzmieniem przepisu jest „ośrodek pomocy społecznej”, co potwierdza dodatkowo brzmienie art. 16 ust. 6 u.s.u.s., wskazującego ośrodek pomocy społecznej jako podmiot finansujący całość składek oraz brzmienie art. 4 pkt 2 lit. k u.s.u.s., określającego ten ośrodek jako płatnika składek. W tym przypadku bowiem ustawodawca wskazuje, że sprawowanie opieki traktuje jako tytuł ubezpieczenia (,zasady podlegania ubezpieczeniom emerytalnemu i rentowym...").

Innego sformułowania ustawodawca użył w art. 6 ust. 2a u.s.u.s., z którego wynika, że za osobę pobierającą świadczenie pielęgnacyjne, specjalny zasiłek opiekuńczy albo zasiłek dla opiekuna wójt, burmistrz lub prezydent miasta opłaca składkę na ubezpieczenia emerytalne i rentowe. $\mathrm{W}$ tym przypadku $\mathrm{z}$ art. 16 ust. $6 \mathrm{~b}$ u.s.u.s. wynika, że składki na ubezpieczenia emerytalne i rentowe osób pobierających świadczenia opiekuńcze określone w art. 16a i 17 u.ś.r. lub zasiłek dla opiekuna finansuje w całości wójt, burmistrz lub prezydent miasta, który jest również płatnikiem dla tychże osób (art. 4 pkt 2 lit. w u.s.u.s.).

Należy zatem zwrócić uwagę, że w pierwszym przypadku ustawodawca posługuje się pojęciem „zasady podlegania ubezpieczeniom”, co sugeruje, że sprawowanie opieki w przypadkach określonych $\mathrm{w}$ art. 6 ust. 2 u.s.u.s. jest tytułem ubezpieczenia, a w przypadkach określonych $\mathrm{w}$ art. 6 ust. 2a u.s.u.s. nie jest tytułem ubezpieczenia, ale jedynie okresem, za który opłaca się składki (choć nie jest to okres podlegania ubezpieczeniom emerytalnemu i rentowym). Analiza przepisów art. 42 ust. 1 u.s.u.s. prowadzi jednak do wniosku, że ustawodawca wykazuje się pewną niekonsekwencją, mając bowiem na uwadze art. 6 ust. 2 u.s.u.s., art. 42 u.p.s., powinien regulować „zasady podlegania” (a zatem językowo powinien brzmieć „obowiązkowo ubezpieczeniom emerytalnemu i rentowym podlegają osoby...”), ustawodawca zaś w u.p.s. posługuje się sformułowaniem analogicznym do tego, które zawiera art. 6 ust. 2a u.s.u.s. („ośrodek pomocy społecznej opłaca składkę”). Takie sformułowanie ustawodawcy może być jednak celowe i wskazywać, że nie zamierzał on traktować sprawowania opieki jako klasycznego tytułu ubezpieczenia, leczjedynie stworzyć pewne mechanizmy mające na celu zrekompensowanie w ramach ubezpieczenia emerytalnego i rentowych negatywnych konsekwencji rezygnacji z zatrudnienia lub jego niepodjęcia, co jest spowodowane w tym przypadku innymi doniosłymi społecznie względami uzasadniającymi takową rekompensatę. 
Argumentem potwierdzającym taką interpretację jest to, że w obu przypadkach przepisy art. 6 ust. 2 u.s.u.s. w zw. z art. 42 ust. 4 u.p.s. oraz art. 6 ust. $2 \mathrm{a}$ u.s.u.s. przewidują, że składka jest opłacana przez okres sprawowania opieki, nie dłużej jednak niż przez okres niezbędny do uzyskania okresu ubezpieczenia (składkowego i nieskładkowego) wynoszącego 20 lat dla kobiet i 25 lat dla mężczyzn. Oznacza to, że po osiągnięciu przez nieformalnego opiekuna wymaganego stażu ubezpieczeniowego (gwarantującego emeryturę w minimalnej wysokości zgodnie $\mathrm{z}$ art. 87 ust. 1 u.e.r.f.u.s. ${ }^{15}$ ), nawet jeśli opieka $\mathrm{w}$ dalszym ciągu jest sprawowana i spełnione są przesłanki wynikające z przepisów u.p.s. lub u.ś.r., ośrodek pomocy społecznej lub wójt (burmistrz, prezydent miasta) nie odprowadzają w dalszym zakresie składek za opiekuna. Tym samym przyjęta konstrukcja prawna jest konstrukcją odmienną od klasycznego tytułu ubezpieczenia emerytalnego i rentowych, gdzie istotą jest automatyzm i przymus polegający na tym, że przez cały okres prowadzenia działalności, która jest tytułem ubezpieczenia, istnieje obowiązek odprowadzania składek.

Taką koncepcję potwierdza również wykładnia systemowa art. 6 u.s.u.s. gdyby ustawodawca chciał traktować sprawowanie opieki jako tytuł ubezpieczenia w sytuacjach wskazanych $\mathrm{w}$ art. 6 ust. 2-2a u.s.u.s., wymieniłby te sytuacje w katalogu tytułów ubezpieczenia określonym w ustępie pierwszym. Wyodrębnienie akurat tych sytuacji do innej jednostki redakcyjnej tekstu prawnego świadczy o tym, że ustawodawca chciał, aby były one traktowane inaczej niż pozostałe tytuły ubezpieczenia określone w art. 6 ust. 1 u.s.u.s. Te argumenty wykładni językowej i systemowej przemawiają za uznaniem, że sprawowanie opieki nie jest dla nieformalnego opiekuna tytułem podlegania ubezpieczeniom emerytalnemu i rentowym, to znaczy, że nie podlegają oni tym ubezpieczeniom, choć za okresy sprawowania opieki w określonym wymiarze opłacane są składki. Przyjęcie takiej interpretacji i wyróżnienie innej od „tytułu ubezpieczenia” czy „podlegania ubezpieczeniu" konstrukcji prawnej, jaką jest konstrukcja, którą można określić roboczo jako konstrukcję „opłacania składki bez podlegania ubezpieczeniom”, ma jednak doniosłe konsekwencje praktyczne, widoczne właśnie w przypadku ubezpieczenia wypadkowego opiekunów.

\section{PODLEGANIE OPIEKUNÓW UBEZPIECZENIU WYPADKOWEMU?}

Podleganie ubezpieczeniu emerytalnemu implikuje co do zasady obowiązek podlegania również ubezpieczeniu wypadkowemu, a co za tym idzie nabycia ochrony ubezpieczeniowej w razie wystąpienia wypadku przy pracy. Konstrukcja prawna przyjęta przez ustawodawcę w art. 12 u.s.u.s. polega na tym, że ubezpie-

15 Ustawa z dnia 17 grudnia 1998 roku o emeryturach i rentach z Funduszu Ubezpieczeń Społecznych, tekst jedn. Dz.U. z 2018 r. poz. 1270 ze zm. (dalej: u.e.r.f.u.s.). 
czeniu wypadkowemu obowiązkowo podlegają osoby podlegające ubezpieczeniom emerytalnemu i rentowym, z wyjątkiem osób wyraźnie wskazanych w ust. 2 tegoż artykułu, który implicite wyłącza taki obowiązek w odniesieniu do enumeratywnie wskazanych grup ubezpieczonych. Z obowiązku ubezpieczenia wypadkowego zostali zwolnieni bezrobotni pobierający zasiłek dla bezrobotnych lub świadczenie integracyjne, posłowie do Parlamentu Europejskiego, o których mowa w art. 1 ust. 1 ustawy z dnia 30 lipca 2004 roku o uposażeniu posłów do Parlamentu Europejskiego wybranych w Rzeczypospolitej Polskiej, oraz osoby, o których mowa w art. 6 ust. 1 pkt 2, 11, 19-22, art. 6a i art. 7 ustawy systemowej.

Wyłączenie określone w art. 12 ust. 2 u.s.u.s. nie obejmuje zatem opiekunów osób niesamodzielnych, o których mowa w art. 6 ust. 2-2a u.s.u.s., co powinno prowadzić do wniosku, że podlegając ubezpieczeniom emerytalnemu i rentowym na podstawie tych przepisów, automatycznie podlegają również ubezpieczeniu wypadkowemu i korzystają z ochrony w tym ubezpieczeniu przewidzianej.

W przypadku nieformalnych opiekunów osób niesamodzielnych przyjęta przez ustawodawcę koncepcja „,podlegania ubezpieczeniu”/,obowiązku ubezpieczenia” bądź wyróżnionej przez autora konstrukcji „opłacania składki bez podlegania ubezpieczeniu" determinuje ich podleganie lub niepodleganie ubezpieczeniu wypadkowemu, a zatem również korzystanie z ochrony ubezpieczeniowej w razie zwłaszcza wypadku przy opiece, jaką ono daje. Przy przyjęciu konstrukcji, że opiekunowie podlegają ubezpieczeniom emerytalnemu i rentowym, należałoby konsekwentnie przyjąć, że podlegają również obowiązkowo ubezpieczeniu wypadkowemu. Artykuł 12 ust. 2 u.s.u.s. nie zawiera bowiem wyłączenia obowiązku podlegania temu ubezpieczeniu wobec osób określonych w art. 6 ust. 2-2a u.s.u.s. Tym samym za opiekunów należałoby opłacać składki na ubezpieczenie wypadkowe i zagwarantować świadczenia w razie wystąpienia wypadku, który można by określić jako wypadek przy opiece, a który jednocześnie powinien zostać wskazany w art. 3 ust. 3 ustawy z dnia 30 października 2002 roku o ubezpieczeniu społecznym $\mathrm{z}$ tytułu wypadków przy pracy i chorób zawodowych ${ }^{16}$ jako jeden $\mathrm{z}$ rodzajów tak zwanych niepracowniczych wypadków przy pracy ${ }^{17}$. Artykuł 3 ust. 1 powołanej ustawy zawiera definicję wypadku przy pracy, art. 3 ust. 3 zaś enumeratywne wskazanie okoliczności, w razie których wykonywania wystąpienie nagłego zdarzenia spowodowanego przyczyną zewnętrzną i powodującego uraz lub śmierć jest traktowane jako wypadek przy pracy ${ }^{18}$. Analiza tego katalogu prowadzi do wniosku, że wskazane w nim okoliczności odnoszą się do poszczególnych tytułów ubezpieczenia wypadkowego określonych w art. 12 ust. 1 w związku z art. 6 ust. 1 u.s.u.s., co oznacza, że wypadkiem niepracowniczym nie

16 Tekst jedn. Dz.U. z 2018 r. poz. 1376 (dalej: u.u.s.w.p.p.).

17 R. Babińska-Górecka, Wypadek niepracowniczy, [w:] Wielka Encyklopedia Prawa, t. 12..., s. $349-350$.

18 D.E. Lach, [w:] Ustawa o ubezpieczeniu społecznym z tytutu wypadków przy pracy i chorób zawodowych. Komentarz, red. D.E. Lach, S. Samol, K. Ślebzak, Warszawa 2010, s. 49. 
jest wypadek doznany w związku ze sprawowaniem opieki, nie zawiera bowiem wypadku doznanego przez nieformalnego opiekuna, o których mowa w art. 6 ust. 2-2a u.s.u.s. Jak wskazałem, art. 3 ust. 3 ustawy wypadkowej zawiera enumeratywne wyliczenie, a zatem nie jest możliwe jego uzupełnienie o wypadek doznany w sytuacjach określonych w art. 6 ust. 2-2a u.s.u.s. w drodze wykładni. Jako przepis prawa ubezpieczeń społecznych podlega on ścisłej wykładni.

Poczyniona analiza potwierdza dodatkowo, że ustawodawca sprawowania opieki nie traktuje jako tytułu ubezpieczenia emerytalnego i rentowego, ale jedynie jako okres opłacania składek. Za wyodrębnieniem takiej konstrukcji może przemawiać również analiza przepisów u.e.r.f.u.s., w której za okres składkowy uznaje się okres ubezpieczenia (art. 6 ust. 1 pkt 1 u.e.r.f.u.s.), który jednak nie jest zdefiniowany jako okres podlegania ubezpieczeniom emerytalnemu i rentowym, ale właśnie jako „okres opłacania składek [wyróżnienie - A.P.] na ubezpieczenia emerytalne i rentowe oraz okres nieopłacania składek z powodu przekroczenia $\mathrm{w}$ trakcie roku kalendarzowego kwoty rocznej podstawy wymiaru składek, o którym mowa w przepisach o systemie ubezpieczeń społecznych" (art. 4 pkt 5 e.r.f.u.s.) ${ }^{19}$. Taka definicja sprawia, że w ubezpieczeniach emerytalnym i rentowych konstrukcja ta pozwala uwzględnić okresy opłacania składek za nieformalnych opiekunów przy ustalaniu prawa do świadczenia i jego wysokości. W ustawie wypadkowej natomiast pojęcie „okres ubezpieczenia wypadkowego" zdefiniowane zostało jako „okres podlegania ubezpieczeniu wypadkowemu, a także okres podlegania ubezpieczeniu społecznemu lub zaopatrzeniu emerytalnemu przed dniem 1 stycznia 1999 r." ${ }^{20}$, co oznacza, że świadczenia będą przysługiwać osobie, wobec której ryzyko ubezpieczeniowe ziściło się w okresie podlegania temu ubezpieczeniu, niezależnie od opłacania składki.

\section{PODSUMOWANIE I WNIOSKI DE LEGE FERENDA}

Poczynione rozważania prowadzą do wniosku, że ustawodawca celowo rozróżnia pojęcia „podleganie ubezpieczeniu” i „opłacanie składki” w rozumieniu art. 6 ust. 2-2a u.s.u.s., które nie są równoważne i oznaczają przyjęcie różnych konstrukcji prawnych zapewniających ochronę socjalną na wypadek wystąpienia pewnych sytuacji życiowych. Wyróżniona konstrukcja prawa nie była do tej pory przedmiotem analizy, nie została nawet wyróżniona w literaturze prawa ubezpieczenia społecznego. Wręcz przeciwnie, zdaje się, że autorzy poruszający tę problematykę traktują art. 6 ust. 2 i 6 ust. 2a u.s.u.s. jako „klasyczny” tytuł ubezpie-

19 Zwraca na to uwagę, choć w innym kontekście, D.E. Lach, [w:] Emerytury i renty z Funduszu Ubezpieczeń Społecznych. Komentarz 2013, red. B. Gudowska, K. Ślebzak, Warszawa 2013, nb. 21.

20 Art. 2 pkt 3 u.u.s.w.p.p. 
czenia, czyli sytuację prawną, której zaistnienie powoduje obowiązek podlegania ubezpieczeniom emerytalnemu i rentowym (lub możliwość dobrowolnego objęcia ubezpieczeniem) $)^{21}$.

Przeprowadzona analiza prowadzi jednak do odmiennego wniosku. W odniesieniu do osób rezygnujących z zatrudnienia lub go niepodejmujących w związku z koniecznością sprawowania opieki nad osobą niesamodzielną, sprawowanie opieki nad osobą niesamodzielną nie jest klasycznym tytułem ubezpieczenia społecznego, z którego wynika obowiązek podlegania ubezpieczeniu. Jest to odmienna konstrukcyjnie instytucja prawna, którą roboczo można określić właśnie jako konstrukcja „opłacania składki mimo braku tytułu ubezpieczenia”. Poprzez taką konstrukcję ustawodawca zapewnia nieformalnym opiekunom osób niesamodzielnych rezygnującym z wykonywania pracy zarobkowej swoistą rekompensatę za ich poświęcenie w ubezpieczeniach emerytalnym i rentowych. Konstrukcja ta pozwala im na uzyskanie stażu ubezpieczeniowego (okresu składkowego) i nabycie własnych uprawnień emerytalno-rentowych poprzez zobowiązanie określonych podmiotów do opłacania za okres sprawowania opieki składek na te ubezpieczenia, które następnie mogą być uwzględnione przy ustalaniu prawa do świadczeń przysługujących w ramach tych dwóch działów ubezpieczenia społecznego. Warto zwrócić uwagę, że obowiązek ten ograniczono w ten sposób, że po osiągnięciu stażu ubezpieczeniowego wymaganego do nabycia świadczenia w wysokości minimalnej, składki nie są dalej opłacane, aby nie obciążały budżetu. Także to potwierdza, że sprawowanie opieki nie jest klasycznym tytułem ubezpieczenia społecznego w rozumieniu art. 6 ust. 1 u.s.u.s. Przy takim klasycznym tytule ubezpieczenia, z którym wiąże się obowiązek podlegania ubezpieczeniu, składki należy opłacać tak długo, jak dany tytuł istnieje w odniesieniu do danego ubezpieczonego (art. 13 u.s.u.s.).

Konsekwencją istnienia wyróżnionej konstrukcji prawnej jest jednocześnie pozbawienie nieformalnych opiekunów ochrony ubezpieczenia wypadkowego, albowiem przyjęcie, że sprawowanie opieki w warunkach określonych w art. 6 ust. 2-2a u.s.u.s. nie stanowi tytułu ubezpieczeń emerytalnego i rentowych prowadzi do wniosku, że opiekunowie nie podlegają ubezpieczeniu wypadkowemu, ponieważ zgodnie z art. 12 ust. 1 u.s.u.s. jest ono obowiązkowe dla osób podlegających ubezpieczeniom emerytalnemu i rentowym. Niezawarcie w katalogu niepracowniczych wypadków przy pracy (art. 3 ust. 3 u.u.s.w.p.p.) wypadku podczas sprawowania opieki i pielęgnacji, przy zamkniętym charakterze tego katalogu, potwierdza rezultaty przyjętej wykładni i prawidłowość tezy o zastosowaniu przez

21 Np. I. Jędrasik-Jankowska, Pojęcia i konstrukcje prawna ubezpieczenia społecznego, Warszawa 2016, s. 92; A. Radzisław, [w:] Ustawa o systemie ubezpieczeń społecznych. Komentarz, red. J. Wantoch-Rekowski, Warszawa 2015, s. 52; B. Gudowska, J. Strusińska-Żukowska, [w:] Ustawa o systemie ubezpieczeń społecznych. Komentarz, red. B. Gudowska, J. Strusińska-Żukowska, Warszawa 2014, nb. 326; R. Babińska-Górecka, Tytut ubezpieczenia spotecznego, [w:] Wielka Encyklopedia Prawa, t. $12 \ldots$, s. 308. 
ustawodawcę innej niż podleganie ubezpieczeniom konstrukcji prawnej, pozwalającej wprawdzie na nabywanie uprawnień do świadczeń z ubezpieczenia społecznego, ale wyłącznie w zakresie ubezpieczeń emerytalnego i rentowych.

Jednak niezapewnienie opiekunom świadczeń w razie wypadku przy opiece należy ocenić krytycznie. O ile autor nie dysponuje danymi statystycznymi pozwalającymi potwierdzić, że sprawowanie opieki i pielęgnacja osoby niesamodzielnej to czynności o znacznym stopniu wypadkogenności, o tyle zasady doświadczenia życiowego taką tezę w pełni uzasadniają - są to często czynności wymagające wzmożonego wysiłku zarówno fizycznego, jak i psychicznego, co z istoty rzeczy sprowadza na opiekuna ryzyko doznania określonych urazów (choćby podczas przenoszenia podopiecznego w celu kąpieli czy wnoszenia go po schodach). Przyjęta konstrukcja sprawia, że nieformalny opiekun, mimo istniejącego obiektywnie ryzyka, nie może liczyć na żadne świadczenia, w tym na jednorazowe odszkodowanie, które w tym przypadku powinno być wypłacane niezależnie od tego, czy miało wpływ na zdolność wykonywania pracy zarobkowej. Ten rodzaj świadczenia $\mathrm{z}$ ubezpieczenia wypadkowego nie ma bowiem charakteru kompensującego utracony wskutek wypadku zarobek, ale charakter odszkodowawczy w związku $\mathrm{z}$ doznanym uszczerbkiem na zdrowiu ${ }^{22}$, którego również nieformalni opiekunowie mogą doznać w związku ze sprawowaniem opieki. Tym samym wyłączenie możliwości uzyskania przez opiekunów tego świadczenia przy relatywnie wysokim ryzyku jego doznania należy ocenić krytycznie, a zarazem postulować wprowadzenie określonych rozwiązań prawnych pozwalających na uzyskanie przez opiekunów świadczeń odszkodowawczych mających na celu naprawienie szkody polegającej na doznaniu uszczerbku na zdrowiu doznanej w związku ze sprawowaniem opieki/pielęgnowaniem osoby niesamodzielnej. Możliwe są w tym przypadku co najmniej dwa rozwiązania:

1. odstąpienie od prawnej konstrukcji „opłacania składki” na rzecz klasycznej konstrukcji podlegania ubezpieczeniu (uznanie sprawowania opieki za tytuł ubezpieczenia) lub

2. wprowadzenie nowego rodzaju wypadku w szczególnych okolicznościach, a zatem rozszerzenie katalogu sytuacji uzasadniających przyznanie świadczeń w ramach tak zwanego odszkodowania socjalnego ${ }^{23}$.

W mojej ocenie do czasu wprowadzenia w Polsce kompleksowego rozwiązania zapewniającego świadczenia osobom niesamodzielnym i ich opiekunom, optymalnym i bardziej słusznym z punktu widzenia zasad ubezpieczeń społecznych i systemu zabezpieczenia społecznego rozwiązaniem byłoby rozszerzenie katalogu tak zwanych wypadków w szczególnych okolicznościach ${ }^{24}$, zawartego

22 I. Jędrasik-Jankowska, Pojęcia i konstrukcje..., s. 354.

23 Na temat pojęcia odszkodowania socjalnego zob. szerzej K. Stopka, Świadczenia odszkodowania socjalnego w prawie polskim, Warszawa 2018, s. 231-242.

24 Ibidem, s. 51; K. Stopka, Wypadek w szczególnych okolicznościach, [w:] Wielka Encyklopedia Prawa, t. $12 \ldots$, s. 308. 
w art. 2 ust. 1 ustawy z dnia 30 października 2002 roku o zaopatrzeniu z tytułu wypadków lub chorób zawodowych powstałych w szczególnych okolicznościach ${ }^{25}$. Zaletą takiego rozwiązania byłoby zapewnienie określonych świadczeń nie tylko nieformalnym opiekunom korzystającym z uprawnień wynikających z art. 6 ust. 2-2a u.s.u.s., lecz także drugiej wyodrębnionej kategorii tych osób, czyli opiekunom nierezygnującym z pracy zarobkowej lub rezygnującym z pracy, ale niespełniającym kryterium dochodowego z art. 42 u.p.s. Pozwoliłoby to zapewnić co najmniej jednorazowe odszkodowania za uszczerbki na zdrowiu doznane przez wszystkich nieformalnych opiekunów w związku ze sprawowaniem opieki nad osobą niesamodzielną w przyjętym w niniejszym opracowaniu rozumieniu, niezależnie od tego, czy opiekun zrezygnował z pracy zarobkowej (lub jej nie podjął) oraz czy spełnia kryterium dochodowe określone w art. 42 u.p.s. Ryzyko wystąpienia wypadku przy opiece, który może spowodować uszczerbek na zdrowiu, dotyczy wszakże tak samo wszystkich opiekunów nieformalnych niezależnie od wykonywania innej pracy zarobkowej.

Nie ulega przy tym wątpliwości, że zwłaszcza w starzejącym się społeczeństwie sprawowanie opieki nad osobą niesamodzielną jest doniosłą ze społecznego punktu widzenia czynnością, mającą prospołeczny wymiar i związek z zadaniami realizowanymi przez państwo ${ }^{26}$. Uzasadnione jest zatem jej porównanie do innych sytuacji wymienionych $\mathrm{w}$ art. 2 ust. 1 powołanej ustawy, co prowadzi do wniosku, że z punktu widzenia systemu zabezpieczenia społecznego rozszerzenie katalogu wypadków w szczególnych okolicznościach o wypadek przy opiece byłoby w słusznym rozwiązaniem, zgodnym z jego założeniami. Raz jeszcze jednak na zakończenie należy podkreślić, że rozwiązanie takie powinno być traktowane jako tymczasowe, do czasu wprowadzenia kompleksowego systemu świadczeń dla osób niesamodzielnych i ich opiekunów.

\section{ON THE SOCIAL INSURANCE OF THE CAREGIVERS OF DEPENDENT PERSONS}

\section{Summary}

The author considers whether the caregivers of dependent persons can obtain social accident insurance. In the first place, he defines who should be treated as a caregiver of a dependent person for the purposes of the study. In the following part, he considers the legal structure of paying a contribution towards the pension and disability pension insurance for the caregivers of dependent persons. Applying the language and system interpretation, he concludes that it is a legal construction that is different from the classic insurance entitlement. In the context of caregivers, it has significant legal consequences because it deprives them of the protection of accident insurance. The legal structure applied by the legislator means that they are not subject to this insurance even though care

25 Tekst jedn. Dz.U. z 2013 r. poz. 737 ze zm.

26 Por. K. Stopka, Świadczenia odszkodowania..., s. 142. 
constitutes an increased risk of an accident. Finally, the author postulates that the health damages of caregivers caused by accidents occuring as part of the caring should be protected as part of the social compensation system.

Keywords: social insurance, accident insurance, insurance entitlement, caregivers

\section{BIBLIOGRAFIA}

Bakalarczyk, Deficyt bezpieczeństwa emerytalnego opiekunów osób niesamodzielnych jako skutek dezaktywizujacego zawodowo systemu opieki w Polsce, „Ubezpieczenia Społeczne. Teoria i Praktyka" 2017, nr 4.

Bakalarczyk R., Polityka wsparcia nieformalnych opiekunów niesamodzielnych osób starszych. $\mathrm{Na}$ podstawie zmian prawnych w latach 2003-2015, Warszawa 2018.

Czepulis-Rutkowska Z., Nowe ryzyka socjalne, „Polityka Społeczna” 40, 2013, nr 11-12.

Emerytury i renty z Funduszu Ubezpieczeń Społecznych. Komentarz 2013, red. B. Gudowska, K. Ślebzak, Warszawa 2013.

Jędrasik-Jankowska I., Pojęcia i konstrukcje prawna ubezpieczenia społecznego, Warszawa 2016.

Jędrasik-Jankowska I., Ubezpieczenie społeczne, t. 1. Część ogólna, Warszawa 2003.

Lach D.E., Niesamodzielność jako ryzyko socjalne, Poznań 2018.

Maciejko W., Instytucje pomocy społecznej, Warszawa 2009.

Przybyłowicz A., O pojęciu niesamodzielności w księdze XI niemieckiego kodeksu socjalnego Ubezpieczenie pielegnacyjne, PiZS 2013, nr 10.

Przybyłowicz A., Społeczne ubezpieczenie pielegnacyjne a rola opieki krewniaczej w Niemczech, „Ubezpieczenia Społeczne. Teoria i Praktyka” 2016, nr 4.

Przybyłowicz A., Ubezpieczenie pielegnacyjne w Republice Federalnej Niemiec, Warszawa 2017.

Stopka K., Świadczenia odszkodowania socjalnego w prawie polskim, Warszawa 2018.

Ustawa o systemie ubezpieczeń spolecznych. Komentarz, red. B. Gudowska, J. Strusińska-Żukowska, Warszawa 2014.

Ustawa o systemie ubezpieczeń spolecznych. Komentarz, red. J. Wantoch-Rekowski, Warszawa 2015.

Ustawa o ubezpieczeniu społecznym z tytulu wypadków przy pracy i chorób zawodowych. Komentarz, red. D.E. Lach, S. Samol, K. Ślebzak, Warszawa 2010.

Uścińska G., Ryzyko jako przesłanka ochrony w systemie zabezpieczenia społecznego, „Polityka Społeczna" 40, 2013, nr 11-12.

Wielka Encyklopedia Prawa, t. 12. Prawo socjalne, red. H. Szurgacz, Warszawa 2017. 